\title{
Interannual changes in body fat condition index of minke whales in the Antarctic
}

\author{
Taro Ichii ${ }^{1, *}$, Narimasa Shinohara ${ }^{2}$, Yoshihiro Fujise $^{3}$, Shigetoshi Nishiwaki ${ }^{3}$, \\ Koji Matsuoka ${ }^{3}$ \\ ${ }^{1}$ National Research Institute of Far Seas Fisheries, 5-7-1 Orido, Shimizu, 424-8633 Japan \\ ${ }^{2}$ Faculty of Marine Science and Technology, Tokai University, 20-1, Orido, Shimizu, 424-8610 Japan \\ ${ }^{3}$ The Institute of Cetacean Research, 4-18, Toyomi-cho, Chuo-ku, Tokyo 104-0055, Japan
}

\begin{abstract}
To study whether or not wide-ranging pelagic predators should be affected by localized changes in prey availability, interannual variability in body fat condition index (assessed from girth measurements) of minke whales Balaenoptera acutorostrata was analyzed in relation to their distribution, stomach-content mass and sea-ice extent during the austral summer in the Antarctic Ocean between $130^{\circ} \mathrm{E}$ and $170^{\circ} \mathrm{W}$. The research area comprised offshore, ice-edge and Ross Sea areas. Of the 3 years $(1990 / 91,1992 / 93$ and 1994/95) included in the study, 1994/95 was a year of significantly poor body fat condition compared with the other 2 years. The 1994/95 year was characterized by extensive sea-ice conditions, covering the usually krill-rich slope region throughout the season. Since minke whales were scarce and their stomach-content mass small in the ice-edge area during 1994/95, food availability in the area during the season was considered to be poor as a result of the high sea-ice extent. Antarctic krill Euphausia superba was regularly the dominant prey species throughout the survey area, although on the Ross Sea shelf E. crystallorophias was the codominant prey with E. superba. The spatial distribution of body size and maturity of $E$. superba indicated apparent unsuitability of the Ross Sea area as a nursery and spawning ground for that species. The Ross Sea area was considered to be an area of low food supply throughout the study period, considering the lower level of stomach contents. Paradoxically, this area usually contained numerous minke whales, especially pregnant females. In conclusion, minke whales appear to have been affected by considerable interannual variability in food availability in the ice-edge area, i.e potentially the most krill-rich area along their migratory route.
\end{abstract}

KEY WORDS: Minke whale Balaenoptera acutorostrata Feeding ecology B Body fat condition index Antarctic krill - Euphausia superba Sea ice - Ross Sea

\section{INTRODUCTION}

In the Antarctic Ocean, penguins, seals and baleen whales depend substantially on Antarctic krill Euphausia superba for food. Of these animals, land-based predators, such as breeding penguins and fur seals, the foraging ranges of which are restricted to their breeding colonies, have been shown to have their foraging performance, body condition and reproductive success change in relation to local krill availability (e.g. Bengtson 1988, Croxall et al. 1988, Watanuki et al. 1993).

•E-mail: ichii@enyo.affrc.go.jp
There is, however, little information available on this matter in the case of pelagic predators, such as whales, although speculation exists that they would be less affected by localized changes in food availability because of their greater mobility (SC-CAMLR 1997). Even substantial declines in the overall abundance of krill might not present a problem for whales, as long as at least 1 high concentration of krill existed along their migratory route in the Antarctic (Anon 1997).

The minke whale Balaenoptera acutorostrata has been estimated as consuming $95 \%$ of the total biomass of krill consumed by baleen whales in the Antarctic (Armstrong \& Siegfried, 1991), Considering that minke whales store energy as fat tissue during the feeding 


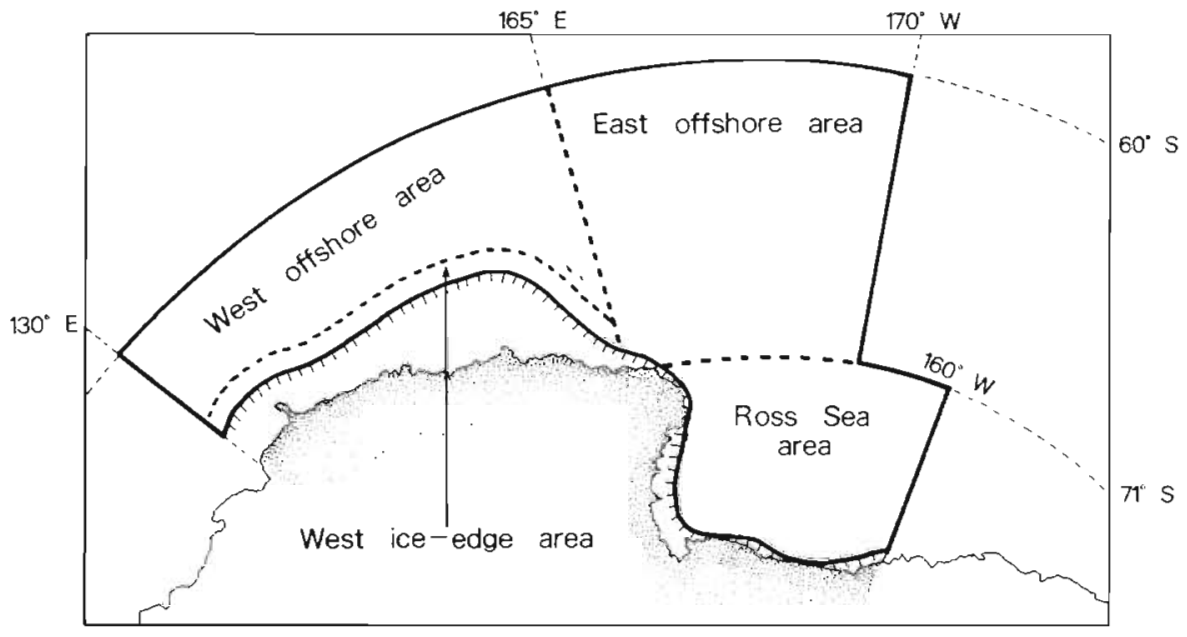

Fig. 1. Map showing the subdivision of the entire research area. (TाT) Ice-edge line region between $60^{\circ}$ and $71^{\circ} \mathrm{S}$ was defined as the east offshore area, and the entire Ross Sea region south of $71^{\circ} \mathrm{S}$ as the Ross Sea area (Fig. 1).

The JARPA survey was conducted from early December to late March. In 1990/91, the research area was surveyed twice (i.e. Legs I and II), but the Ross Sea area was not covered during Leg I due to blockading sea-ice preventing entry (Fig. 2a). In 1992/93 and 1994/95, the entire research area was surveyed once (i.e. Leg II), with parts of the research area also being surveyed before (i.e. Leg I) and after (i.e. Leg III) Leg II (Fig. 2b, c).

A saw-tooth type trackline design was applied to ensure that there was an equal probability of coverage of every point in each area (Fig. 2). Minke whales were taken at random (Fujise et al. 1997), their initial sighting positions being shown in Fig. 2. Samples were taken only from primary sightings. The '2-whale sampling' scheme was used in 1990/91 and the '1-whale sampling' scheme was used in 1992/93 and 1994/95. Under the former scheme, all solitary animals detected were taken, and 2 animals were taken from schools of 2 or more animals. Under the latter scheme, only 1 whale was taken from any school. The whale sampled was determined by using a random-numbers table. Although 4 and 3 dwarf minke whales were taken in 1990/91 and 1992/93, respectively, only specimens having an ordinary form were used for this study. (The dwarf form minke whale is different from the typical minke whale in body size, characters of the baleen plates and the dorsal fin [Best 1985, Arnold et al. 1987].) A summary of the specimens taken is given in Table 1. Data collected included sex, maturity, body length, girth circumference at the position of the umbilicus, body weight, and stomach-content weight and prey species' composition.

Females were considered sexually mature if at least 1 corpus luteum or albicans was present in the ovaries; otherwise they were classified as immature. The presence of a foetus was taken to indicate pregnancy. The detection of a milk-colored fluid was used to classify whales as lactating. Sexual maturity for males was determined by examination to histological examination of testis tissues collected from the center of right testis. Males having seminiferous tubules over $100 \mu \mathrm{m}$ in diameter (average of 15 to 20 measurements) or sperm in the tubules were determined to be sexually mature; the others were classified as being immature (Kato et al. 1990). shore and ice-edge regions were separated by a line $45 \mathrm{n}$ miles from the ice-edge limit. In the east area, that
The Japanese Whale Research Program under Spearea south of $60^{\circ} \mathrm{S}$ in IWC Whaling Management Areas IV $\left(70^{\circ}\right.$ to $\left.130^{\circ} \mathrm{E}\right)$ and $\mathrm{V}\left(130^{\circ} \mathrm{E}\right.$ to $\left.170^{\circ} \mathrm{W}\right)$, being de nual changes in sea-ice extent, compared with Area IV, surveys in the former area (i.e. 1990/91, 1992/93 and 1994/95 surveys) were chosen for this study. The research area was divided into west and east areas along the $165^{\circ} \mathrm{E}$ longitude line (Fig. 1). In the west area, off-

season, body fat condition could be a sensitive indicator of the integrated effects of krill availability during the
austral summer. According to Lockyer (1987), the single most useful indicator of body fat condition in whales is girth circumference, measured approximately mid-
length at the position of the umbilicus, because variations in such reflect not only changes in blubber thickquantitative changes in muscle and visceral fat. Under the auspices of the Japanese Whale Research
Program under Special Permit in the Antarctic (JARPA), girth data of minke whales have been collected every year since 1989/90, such data not having this paper, interannual variations in girth of minke whales are analyzed in relation to their stomach-conto examine whether or not wide-ranging pelagic predators should be affected by localized changes in prey availability.

\section{MATERIALS AND METHODS}



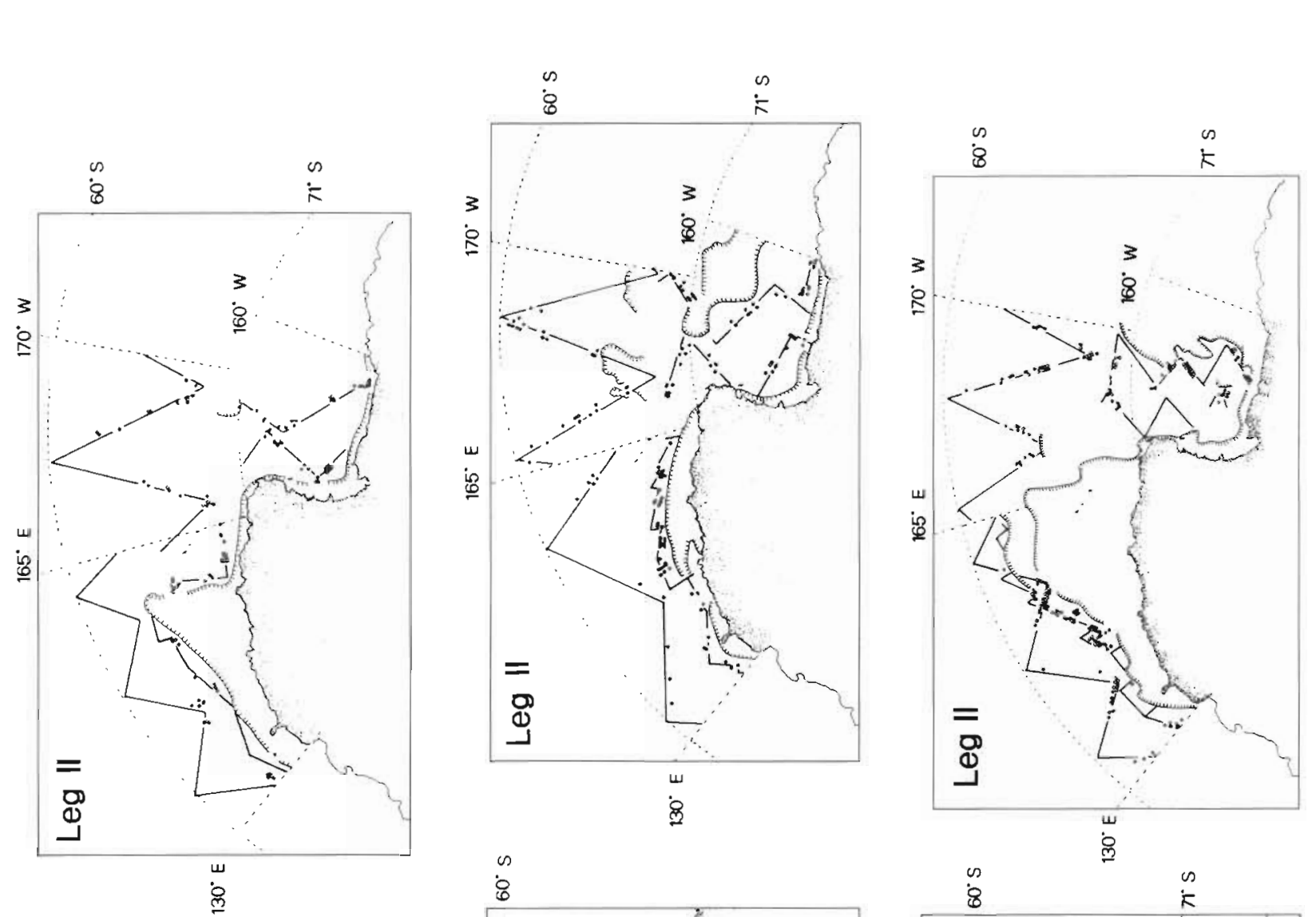

ह
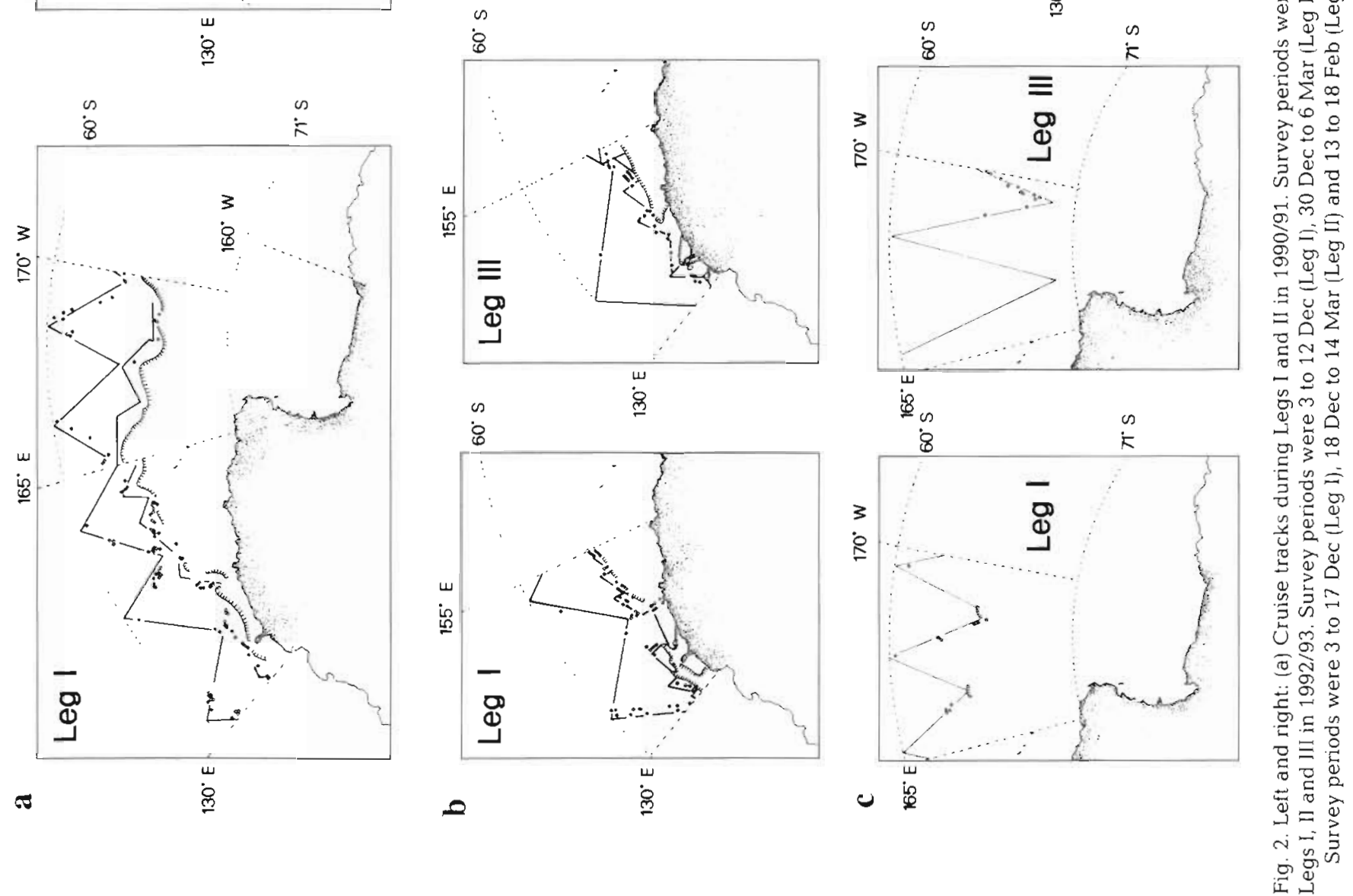
Table 1 Balaenoptera acutorostrata. Reproductive status of minke whales taken by area in each season

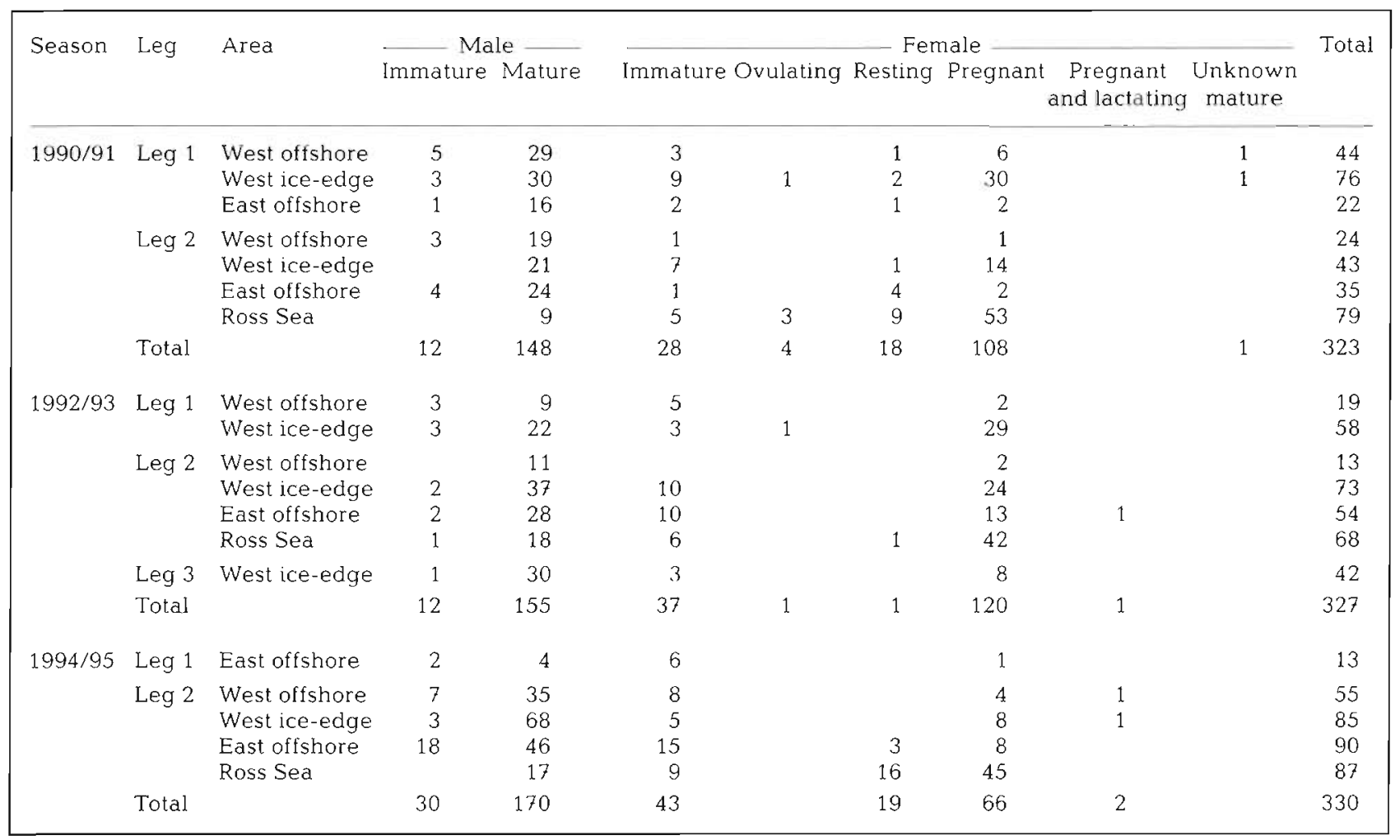

Body length was measured to the nearest $10 \mathrm{~cm}$ from the tip of the upper jaw to the deepest part of the fluke notch along a straight line parallel to the body axis. It was noted that there was no significant difference in body length by year and month for each reproductive class. Girth circumference was in fact measured to the nearest $\mathrm{cm}$ for half girth and later doubled for full girth. Girth circumference being significantly correlated with body length, measurements were expressed as percentages of body length, to enable more precise comparisons. Because there was no statistical difference between girths with higher (50 to $100 \%$ ) or lower (0 to $50 \%$ ) stomach fullness, the latter was not taken into consideration for girth analysis. Body weight was directly measured to the nearest $100 \mathrm{~kg}$ using a $15 \mathrm{t}$ capacity scale.

Bushuev (1986) noted that minke whales tend to feed in the morning in areas of abundant and stable food supply. Hence, the ratio of forestomach content mass to body weight of minke whales caught in the morning was used to evaluate food supply. The numbers of minke whales used for forestomach mass/body weight analyses were 167, 146 and 169 in 1990/91, 1992/93 and 1994/95, respectively.

For identification of food species, stomach-content samples (when relatively fresh) were collected from each whale and preserved in 10\% formalin solution
(31 samples in 1990/91, 116 in 1992/93 and 147 in 1994/95). (The initial low sample number reflects lesser emphasis given to this aspect during the first research season.) When food species included Euphausia superba, between 50 and 200 individuals of the latter were randomly sampled from each stomachcontent sample for body length measurements and maturity stage determination. To ensure 'randomness', individual krill for examination were not selected 'by eye', which may introduce a degree of subjectivity (i.e. selection of larger individuals). Body length was measured to the nearest $\mathrm{mm}$ from the anterior tip of the rostrum to the posterior end of the telson. When krill were partly digested or damaged, body length was calculated from a regression for body length based on carapace length (Ichii \& Kato 1991). The latter was measured from the anterior tip of the rostrum to the mid-dorsal posterior edge of the carapace. Maturity stages were identified according to the classification of Makarov \& Denys (1981).

The density of minke whales is expressed as the number of whales seen per $100 \mathrm{n}$ miles steamed for each $1^{\circ}$ latitude $\times 1^{\circ}$ longitude. Sighting results from Leg II of each survey were used so as to make year-toyear comparisons of minke whale distribution. Information on sea-ice extent was obtained from the U.S. Navy-NOAA. Joint Ice Center. 
Year-to-year differences in girth and stomach-content mass were analyzed with the Mann-Whitney $U$ test. For 3 sample comparisons, following the Bonferroni method, the significance level was divided by 3 (i.e. $\mathrm{p}^{\prime}=\mathrm{p} / 3$ ) to avoid Type I errors (Sokal \& Rohlf 1997).

\section{RESULTS}

\section{Body fat condition}

To indicate body fat condition, mean girth measurements (as \% of body length) by reproductive class and month are shown in Fig. 3. Mean girths from sample sizes under 10 were not included in the analyses. Increases in girth were greatest from January to February during the entire seasonal study period (December to March). February mean girths were significantly less in 1994/95, compared with 1990/91 and 1992/93 $\left(\mathrm{p}^{\prime}<0.003\right)$, in both pregnant females and mature males. February mean girths also tended to be less in 1994/95 than in 1990/91 in immature females although there was no significance $(p=0.06)$.

For more precise comparisons between years, girth data obtained in the same month and area should be compared. Due to inconsistencies in the survey procedure, the Ross Sea area was the only area surveyed during a similar period (mainly February) each year throughout the entire study program. Fig. 4 shows the interannual variability in girth of whales sampled from this area and confirms the above-mentioned interannual girth variations, i.e. significantly smaller in $1994 / 95$ than in 1990/91 and 1992/93 ( $\left.p^{\prime}<0.003\right)$ for pregnant females, and significantly smaller in 1994/95 than in 1992/93 $(\mathrm{p}<0.05)$ for mature males.

\section{Ice-edge distribution}

Sea-ice distributions in the middle of each month during the austral summer are shown in Fig. 5, 'seaice' being defined as sea-ice coverage of $20 \%$ or more. The ice-edge retreated from December to February and then started to expand in March. The icebound entrance to the Ross Sea became ice-free from mid- to late January. Sea-ice usually remained in the eastern Ross Sea, often with a belt extending from east to west seaward of the shelf slope during mid-summer.

Interannual variability in sea-ice distribution was great, particularly in the waters off George $V$ Land $\left(150^{\circ}\right.$ to $\left.170^{\circ} \mathrm{E}\right)$. Sea-ice in the latter extended as far as or beyond the Balleny Islands throughout the 1994/95 study period, but was considerably less in 1990/91 and 1992/93 (Fig. 5).

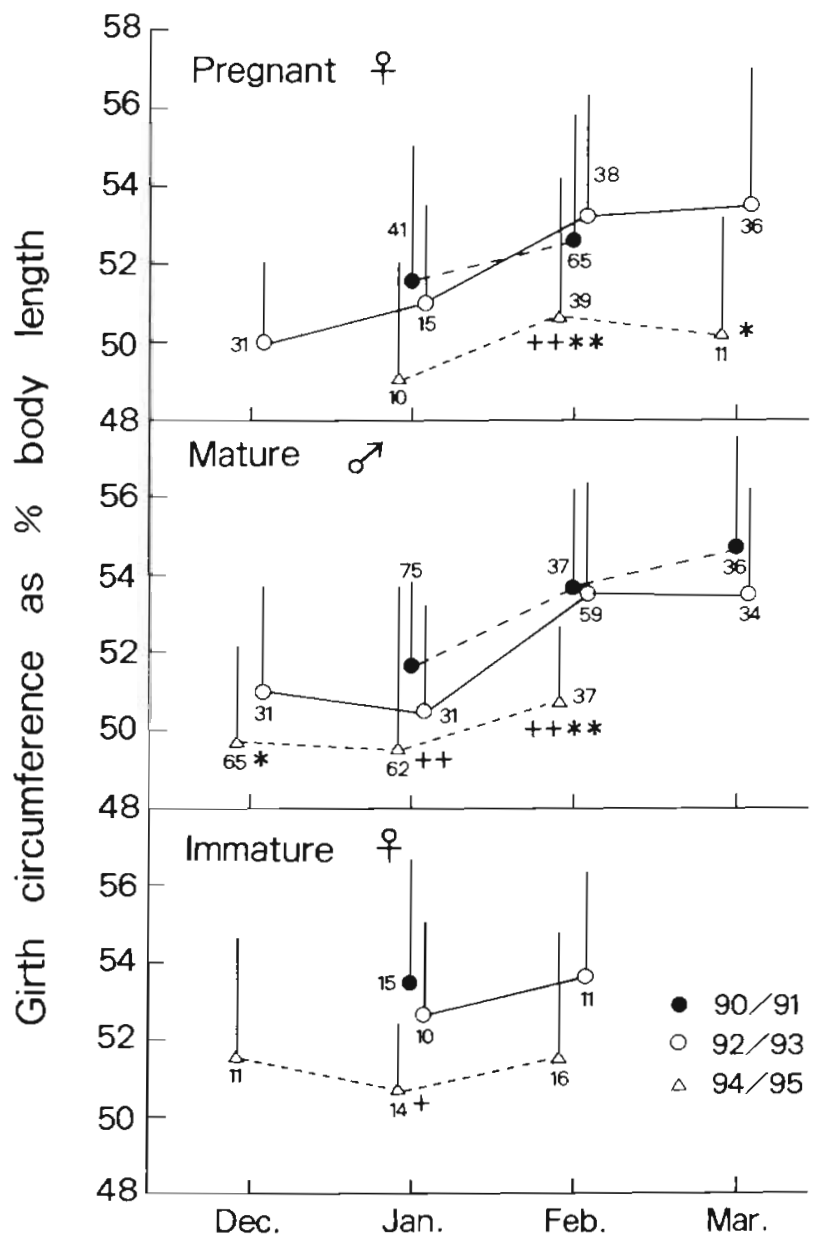

Fig. 3. Balaenoptera acutorostrata. Monthly and interannual changes in body fat condition by reproductive class. Body fat condition expressed as girth $(\mathrm{cm}) /$ body length $(\mathrm{m})$. Mean + SD and sample sizes are shown. (++**) $1994 / 95$ year significantly different to 2 previous years $\left(\mathrm{p}^{\prime}<0.003\right)$; $(++) 1994 / 95$ year significantly different to $1990 / 91$ year $\left(p^{\prime}<0.003\right)$ but not to $1992 / 93$ year; $(+) 1994 / 95$ year significantly different to $1990 / 91$ year ( $p^{\prime}<0.017$ ) but not to $1992 / 93$ year; $(*) 1994 / 95$ year significantly different to $1992 / 93$ year $(p<0.05)$

\section{Distribution of minke whales}

The distribution of minke whales showed considerable interannual variability, reflecting similar variability in sea-ice extent (Fig. 6). A high density of minke whales (>500 ind./100 n miles) was mainly associated with a combination of shelf slope and sea-ice factors in the west area and in the Ross Sea area (Fig. 6). During 1994/95, when the ice-edge in the west area extended far offshore, minke whales were scarce in the west iceedge area, but extraordinarily abundant in the eastern part of the Ross Sea area. On the other hand, during 1990/91 and 1992/93, when the ice-edge in the west area coincided more or less with the slope, high concentrations of minke whales were found in the west 


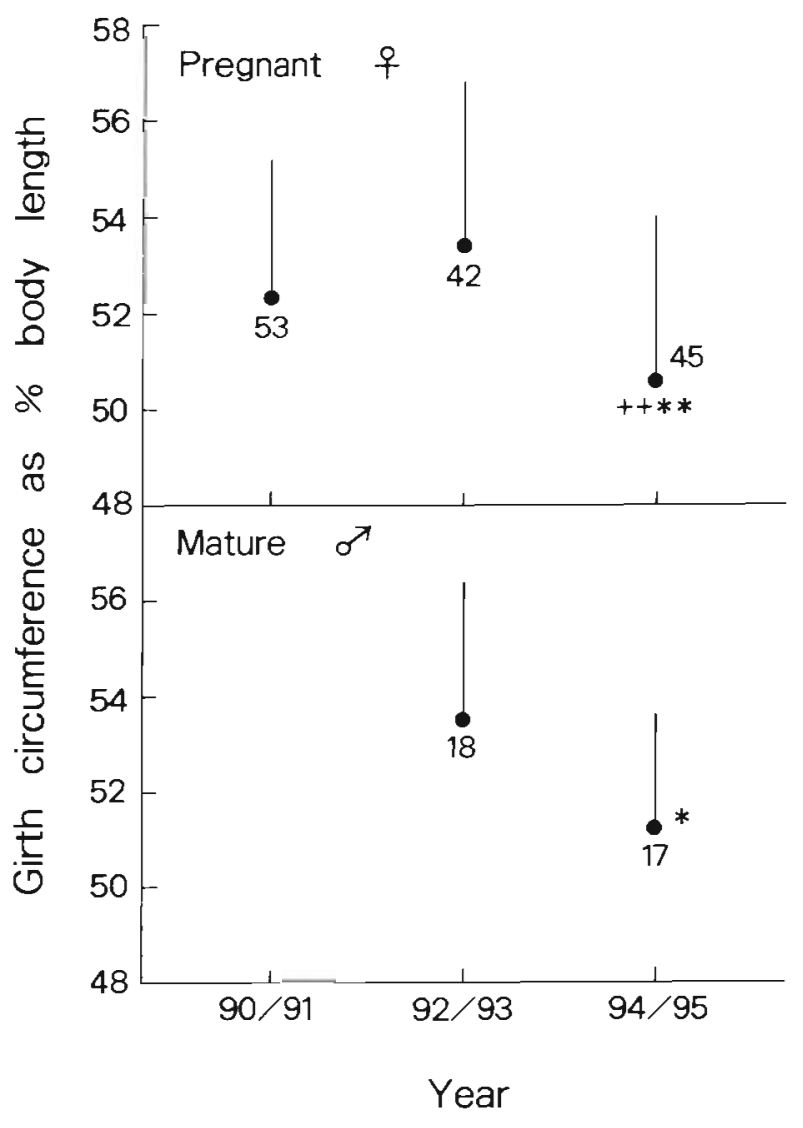

Fig. 4. Balaenoptera acutorostrata. Interannual changes in body fat condition by reproductive class in the Ross Sea area (see Fig. 3 legend). Survey periods were 6 to $14 \mathrm{Feb}(1990 / 91$ ),

17 Feb to 6 Mar (1992/93) and 23 Feb to 11 Mar (1994/95) ice-edge area, as well as in the Ross Sea area. The density of minke whales throughout the west and east offshore areas was low throughout the entire study period.

\section{Segregation of minke whales}

To examine segregation of minke whales by reproductive class, the proportion of the population by reproductive class and area to the total population during Leg II is shown in Table 2. This table was constructed in such a way that reproductive class composition of the samples in each area was weighted by the estimated population in that area during Leg II (Nishiwaki et al. 1997a). It should be noted that the total estimated population was approximately the same throughout the survey period (Nishiwaki et al. 1997a). Pregnant females and mature males were codominant in the total population, comprising 39 to $40 \%$ and 31 to $47 \%$, respectively. It was apparent that pregnant females were very abundant in the Ross Sea area, whereas mature males showed similar levels of abundance in each area. In 1994/95, a substantial proportion $(71 \%)$ of the total estimated population was distributed in the Ross Sea area, with only a small proportion $(3 \%)$ being distributed in the west ice-edge area. As a result, not only pregnant minke whales but also other reproductive classes, such as mature males, immature females and resting females, tended to congregate in the Ross Sea.

Table 2. Balaenoptera acutorostrata. Proportion of the minke whale population by reproductive class and area to the total estimated population during Leg II

\begin{tabular}{|c|c|c|c|c|c|c|c|c|c|c|}
\hline \multirow[t]{2}{*}{ Season } & \multirow[t]{2}{*}{ Area } & \multicolumn{2}{|c|}{ Male $\longrightarrow$} & \multicolumn{6}{|c|}{$\longrightarrow$ Female } & \multirow[t]{2}{*}{ Total } \\
\hline & & Immature & Mature & Immature & vulating & Resting & Pregnant & $\begin{array}{c}\text { Pregnant } \\
\text { and lactating }\end{array}$ & $\begin{array}{l}\text { Unknown } \\
\text { mature }\end{array}$ & \\
\hline \multirow[t]{5}{*}{$1990 / 91$} & West offshore & 1.2 & 7.7 & 0.4 & 0.0 & 0.0 & 0.4 & 0.0 & 0.0 & 9.7 \\
\hline & West ice-edge & 0.0 & 10.0 & 3.3 & 0.0 & 0.5 & 6.7 & 0.0 & 0.0 & 20.4 \\
\hline & East offshore & 2.5 & 1.5 .2 & 0.6 & 0.0 & 2.5 & 1.3 & 0.0 & 0.0 & 22.2 \\
\hline & Ross Sea & 0.0 & 5.4 & 3.0 & 1.8 & 5.4 & 32.0 & 0.0 & 0.0 & 47.7 \\
\hline & Total & 3.7 & 38.3 & 7.4 & 1.8 & 8.4 & 40.3 & 0.0 & 0.0 & 100.0 \\
\hline \multirow[t]{5}{*}{$1992 / 93$} & West offshore & 0.0 & 14.5 & 0.0 & 0.0 & 0.0 & 2.6 & 0.0 & 0.0 & 17.1 \\
\hline & West ice-edge & 0.6 & 10.3 & 2.8 & 0.0 & 0.0 & 6.7 & 0.0 & 0.0 & 20.2 \\
\hline & East offshore & 0.8 & 10.9 & 3.9 & 0.0 & 0.0 & 5.0 & 0.4 & 0.0 & 21.0 \\
\hline & Ross Sea & 0.6 & 11.0 & 3.7 & 0.0 & 0.6 & 25.7 & 0.0 & 0.0 & 41.7 \\
\hline & Total & 1.9 & 46.7 & 10.3 & 0.0 & 0.6 & 40.1 & 0.4 & 0.0 & 100.0 \\
\hline \multirow[t]{5}{*}{$1994 / 95$} & West offshore & 1.0 & 5.2 & 1.2 & 0.0 & 0.0 & 0.6 & 0.1 & 0.0 & 8.1 \\
\hline & West ice-edge & 0.1 & 2.7 & 0.2 & 0.0 & 0.0 & 0.3 & 0.0 & 0.0 & 3.4 \\
\hline & East offshore & 3.5 & 9.1 & 3.0 & 0.0 & 0.6 & 1.6 & 0.0 & 0.0 & 17.7 \\
\hline & Ross Sea & 0.0 & 13.8 & 7.3 & 0.0 & 13.0 & 36.6 & 0.0 & 0.0 & 70.8 \\
\hline & Total & 4.7 & 30.8 & 1.1 .7 & 0.0 & 13.6 & 39.1 & 0.2 & 0.0 & 100.0 \\
\hline
\end{tabular}



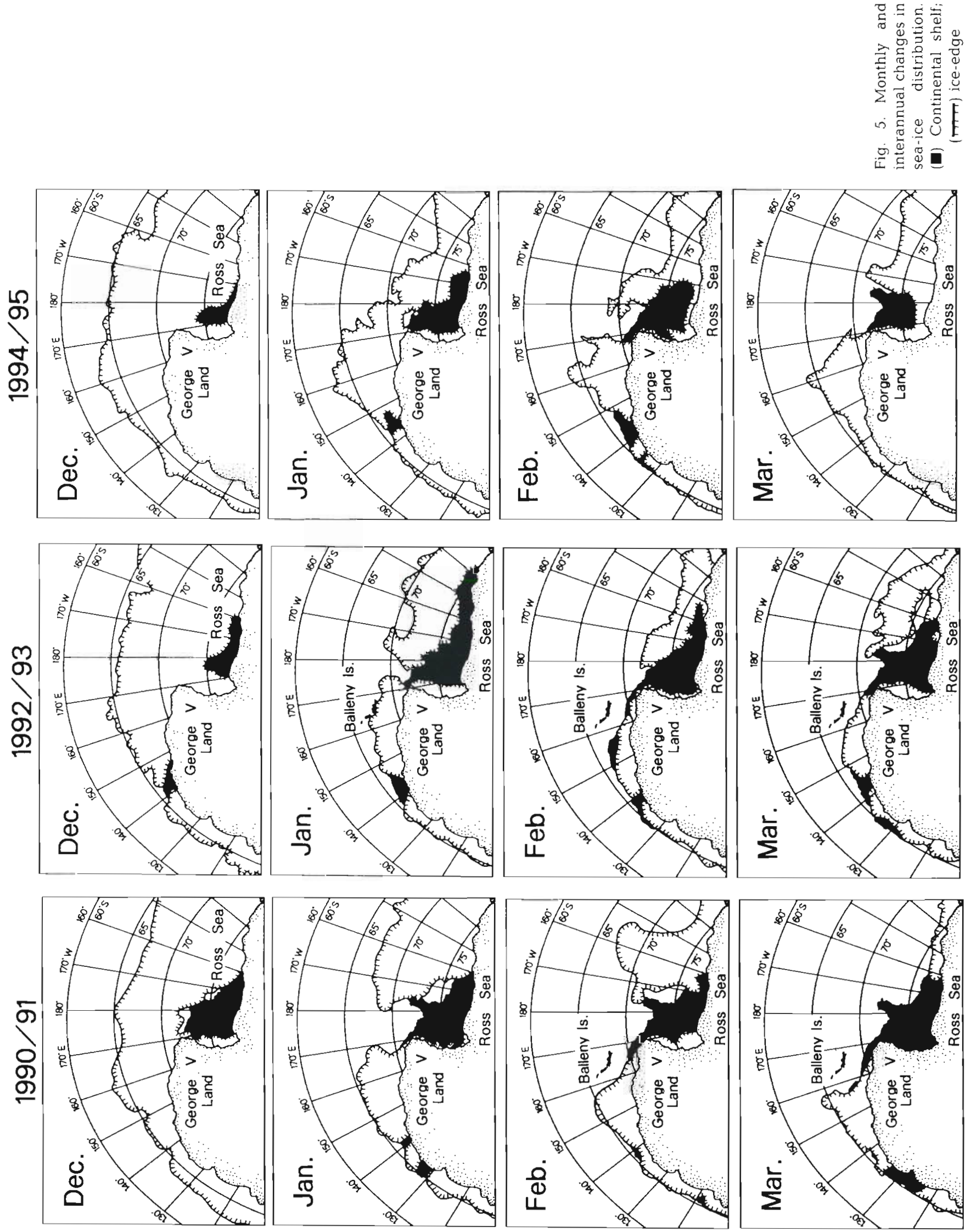

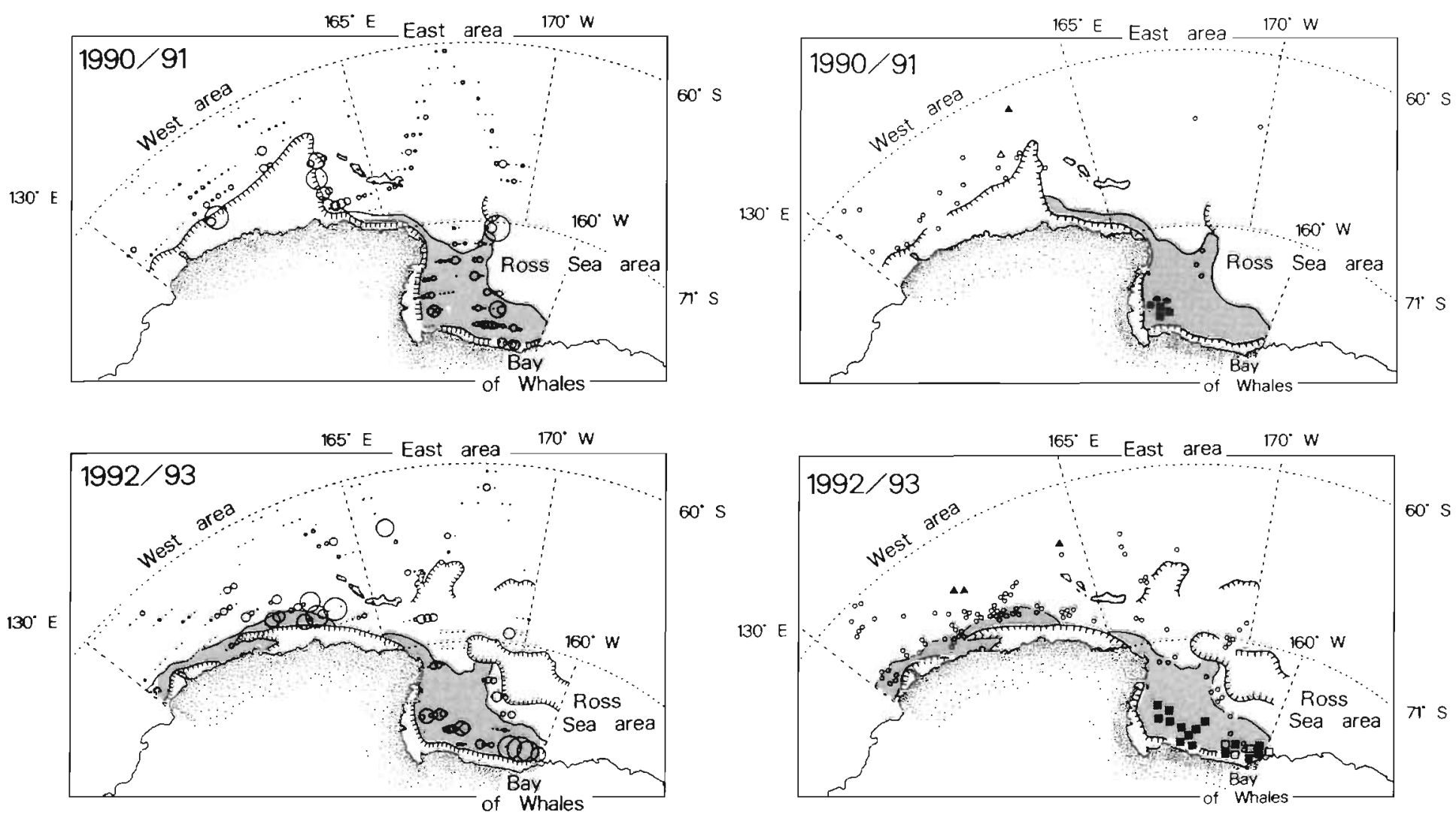

$60^{\circ} \mathrm{s}$
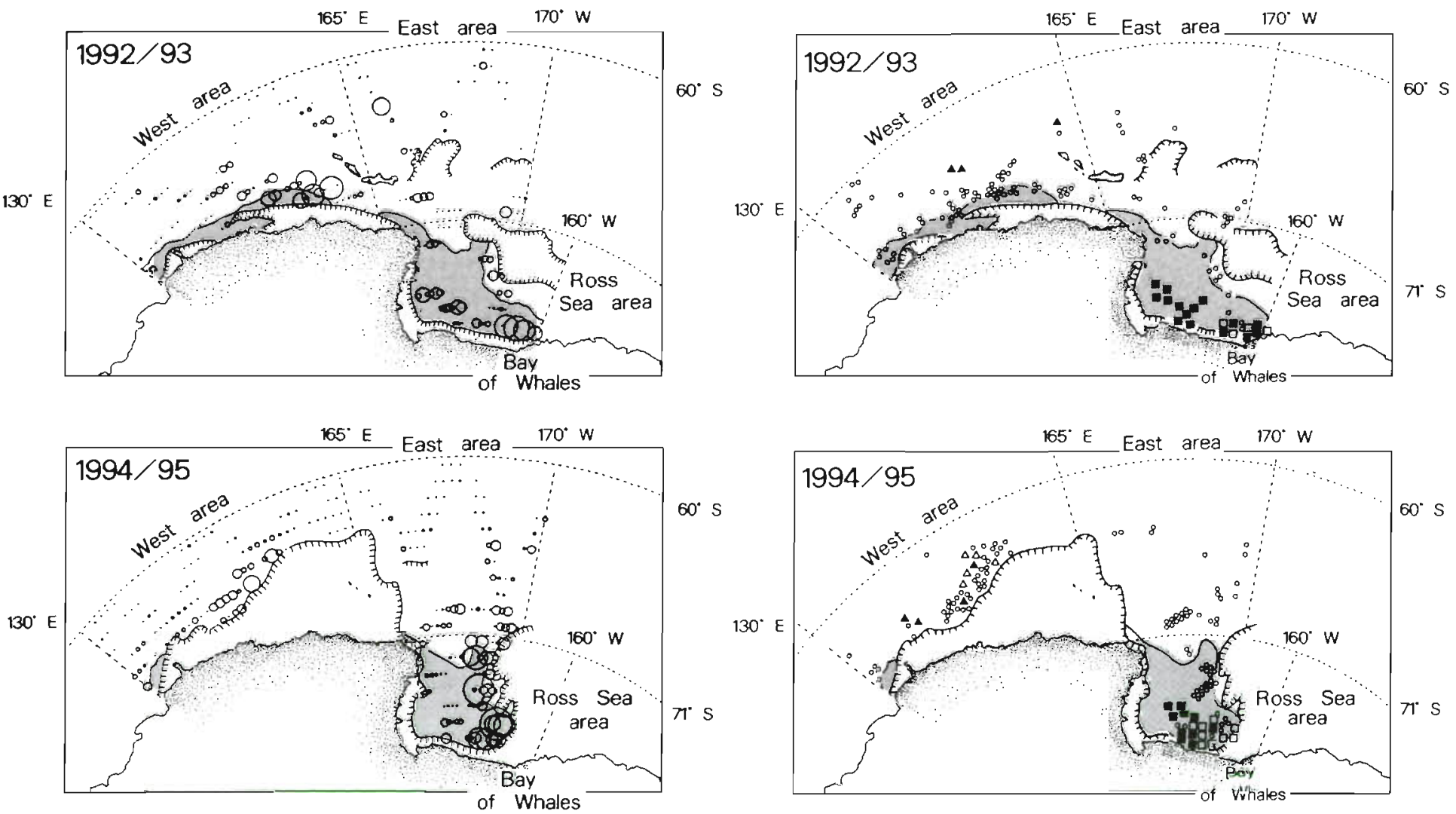

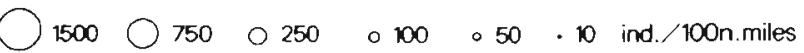

Fig. 6. Balaenoptera acutorostrata. Distribution of minke whales. Density of whales expressed as number seen per. $100 \mathrm{n}$ miles steamed. Shaded area: continental shelf; $(\pi \pi T)$ ice-edge

\section{Prey species}

Prey species showed little substantial interannual variability (Fig. 7). Euphausia superba was the dominant food species throughout the survey areas except in the southern part of the Ross Sea area. In the latter

Fig. 7 Balaenoptera acutorostrata. Occurrence and distribution of food organisms in the stomachs of minke whales. (O) Euphausia superba only, ( $)$ dominant occurrence of E. crystallorophias, ( $\square$ ) subordinate occurrence of $E$. crystallorophias with E. superba, $(\mathbf{\Delta})$ dominant occurrence of Thysanoessa macrura, $(\Delta)$ subordinate occurrence of $T$ macrura with $E$. superba, (O) dominant occurrence of Pleuragramma antarcticum. Shaded area: continental shelf; (TrT) ice-edge

area, E. crystallorophias, a neritic euphausiid, was exclusively the dominant food species on the shelf and codominant with E. superba in the vicinity of the Bay of Whales, where minke whales were very abundant. In 1990/91. Antarctic silverfish Pleuragramma antarcticum became an important food on the southeast shelf 
of the Ross Sea area, in addition to $E$. crystallorophias. In 1994/95, a year of strong sea-ice extent, Thysanoessa macrura, an oceanic euphausiid, was a frequent prey species in the west area, compared with the other 2 years. This may be due to the offshore shift of the minke whale distribution pattern, resulting from the greater extent of sea-ice

\section{Body sizes and maturity stages of Euphausia superba}

Body size compositions of Euphausia superba by area are shown in Fig. 8, which were constructed by combining krill size composition (shown by relative percentage) from each stomach. $E$. superba spatial distribution showed a similar pattern throughout the entire study period, being characterized by bi- or multi-modal compositions (modes at 21 to $53 \mathrm{~mm}$ ), with the frequent occurrence of small individuals ( $\leq 30 \mathrm{~mm}$ ) in all areas except the Ross Sea area. In the latter, they were characterized by uni-modal compositions (modes at 43 to $49 \mathrm{~mm}$ ), small individuals being absent.

The maturity stages of large krill $(\geq 40 \mathrm{~mm}$ ) showed interannual variability, the percentage of mature individuals (fully matured [IIIB] males, and copulated [IIIBC], gravid [IIID] and spent [IIIE] females) in samples of large krill being much lower in 1992/93 than in the other years. Within the same year, large krill in the Ross Sea area showed a lower degree of maturation compared with the other areas; the percentages of mature individuals in samples of large krill were lower (in 1990/91) or negligible (in 1992/93 and 1994/95), whereas they were much higher in other areas (Fig. 8)

\section{Stomach-content mass}

Since the abundance of Euphasia superba is strongly influenced by the existence of the continental shelf and sea-ice (e.g. Ichii 1990, Everson \& Goss 1991), the mean forestomach-content weight (as \% of body weight) was calculated by area (Fig. 9).
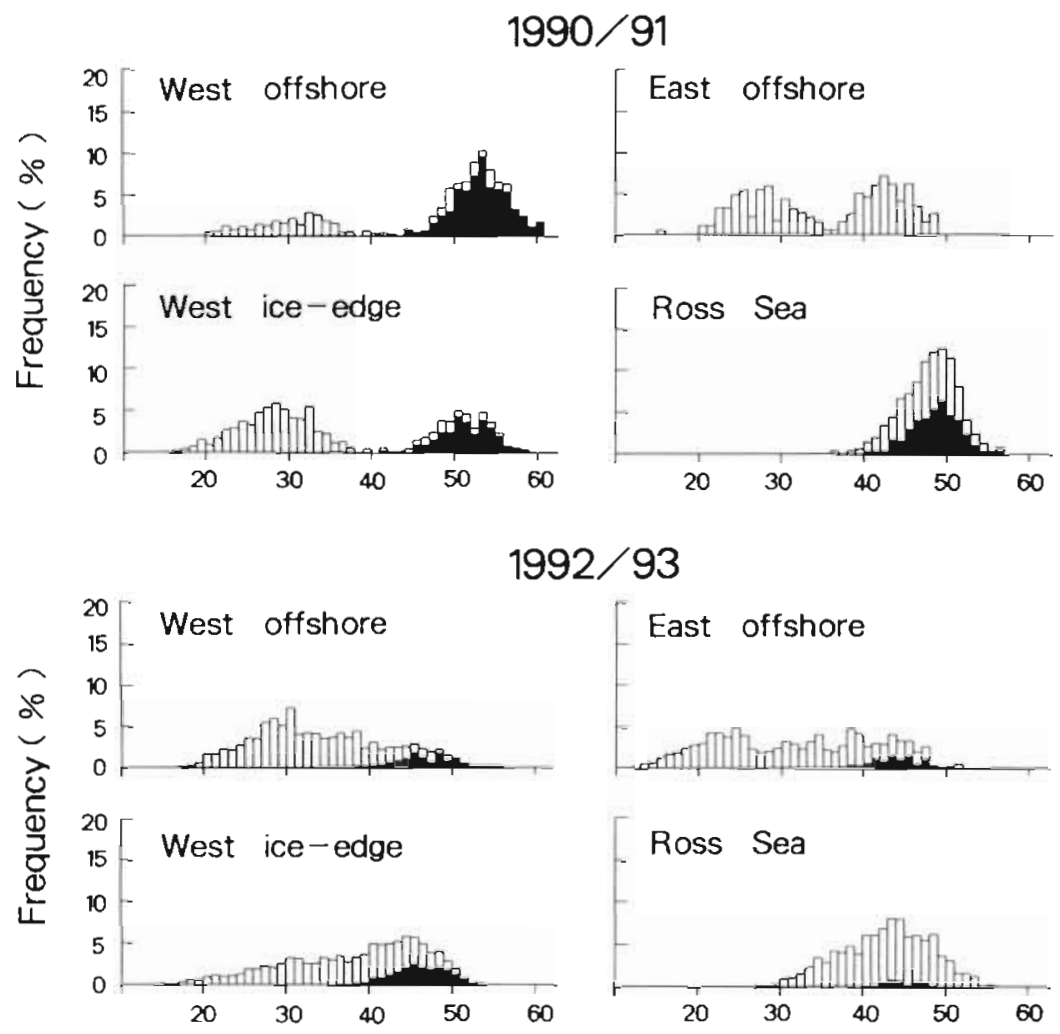

$1992 / 93$

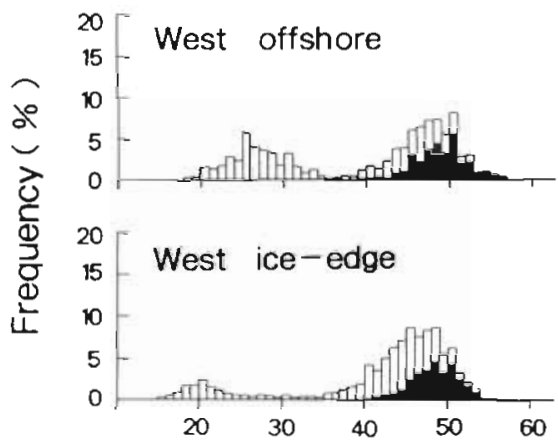

Body length ( $\mathrm{mm}$ )

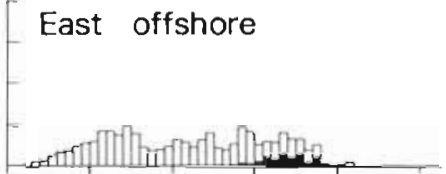

Ross Sea

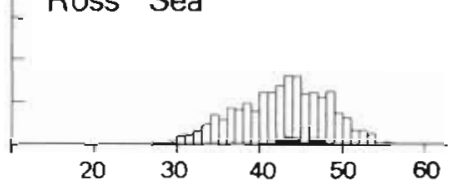

$1994 / 95$

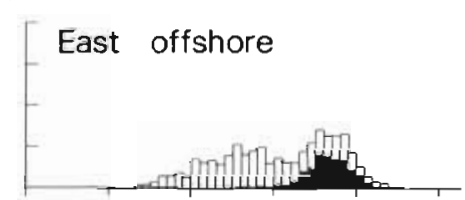

Ross Sea

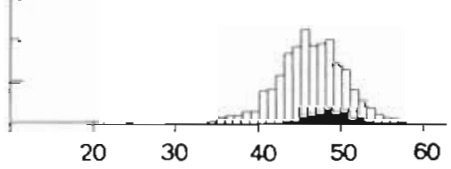

Body length ( $\mathrm{mm}$ )
Fig. 8. Euphausia superba. Body length compositions by area for each year Solid bars: fully mature krill (fully matured [IIIB] males, and copulated [IIIBC] gravid [IIID] and spent [IIIE] females); open bars: less mature or juvenile krill

The stomach-content mass was significantly less in the year of poor body fat condition index (1994/95) than in the 2 good years (1990/91 and 1992/93) in the west ice-edge area $\left(\mathrm{p}^{\prime}<0.017\right.$ and $\mathrm{p}^{\prime}<0.003$, respectively). In the Ross Sea area, on the other hand, stomach-content mass was significantly greater in 1994/95 than in 1990/91 ( $p^{\prime}<0.003$ ) (although the 1992/93 figure did not differ significantly from those of the other 2 seasons). Thus, the interannual variability in stomach- 


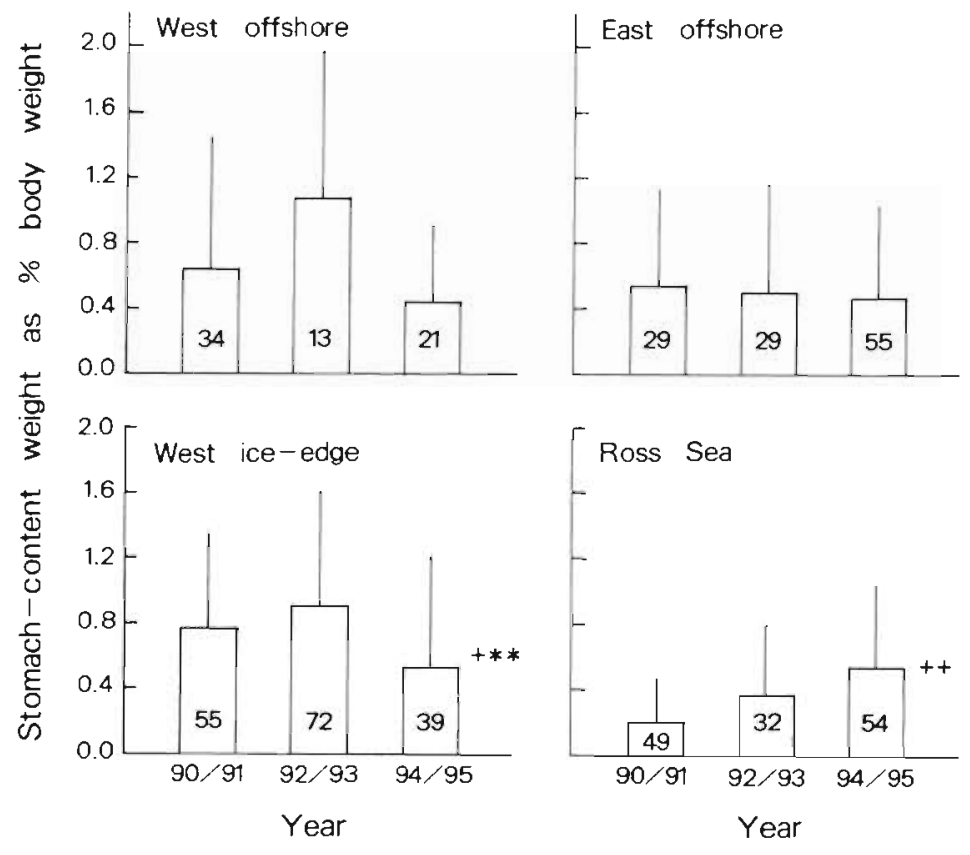

Fig. 9. Balaenoptera acutorostrata. Interannual differences in stomachcontent weight, based on the ratio (\%) of forestomach-content weight to total body weight of minke whales taken in the morning. Mean $+\mathrm{SD}$ and sample sizes are shown. (+**) 1994/95 year significantly different to $1990 / 91$ year $\left(\mathrm{p}^{\prime}<0.017\right)$ and $1992 / 93$ year $\left(\mathrm{p}^{\prime}<0.003\right) ;(++) 1994 / 95$ year significantly different to $1990 / 91$ year $\left(p^{\prime}<0.003\right)$ but not to $1992 / 93$ year

content mass in the west ice-edge area was closely linked to body fat condition index, but that in the Ross Sea area was not. It is notable that the level of stomach-content mass in the west ice-edge area tended to be much higher than that in the Ross Sea area, implying that food availability may be much greater in the former.

\section{DISCUSSION}

\section{Interannual changes in body fat condition index}

Girth measurements of minke whales demonstrated significantly interannual changes in body fat condition index. Of the 3 years $(1990 / 91,1992 / 93$ and 1994/95) included in the study, 1994/95 was a year of significantly poorer body fat condition index than the other 2 years (Fig 3) A similar interannual change in body fat condition index has also been observed in Area IV $\left(70^{\circ}\right.$ to $130^{\circ} \mathrm{E}$ ) (Ichii unpubl. data). It is therefore suggested that interannual changes in energy storage observed in this study may be quite typical, implying the existence of considerable interannual variability in food availability on a wide geographical scale, affecting even highly mobile animals such as minke whales
The relationship between stomach content mass in the ice-edge area and the body fat condition index suggests that the 'strong ice-extent' event in the west ice-edge area could have been one of the important factors linked to low food availability in 1994/95. The continental slope in the western area is known to be a krill-rich area (Ichii 1990). Hence, in the year of strong sea-ice extent, the krill-rich slope region was covered by sea-ice. Furthermore, the west ice-edge area shifted far offshore, where krill tend to be scarce. This may have led to low food availability (low stomach-content mass; Fig. 9) and the very low density of minke whales along the ice-edge (Fig. 6). Consequently, more and more minke whales migrated into the Ross Sea area, while others may have penetrated the pack ice area if there were leads within the ice. On the other hand, in years of less extensive ice-cover (1990/91 and 1992/93), the west ice-edge area was formed more or less along the shelf slope, where krill tend to be abundant. This may have led to high food availability and the high density of minke whales near the ice-edge.

The body fat condition index of minke whales in the Ross Sea area was linked to food availability (stomach-content mass) in the western ice-edge area, not to that in the Ross Sea area, possibly because whales migrated to the Ross Sea area via the western ice-edge area. Furthermore, minke whales were obviously prevented from entering the Ross Sea area by sea-ice until mid- to late January (Fig. 5) and would have had to feed in other areas, such as the ice-edge area, at least until that time. Therefore, in years of high krill availability along the ice-edge, body fat condition would have been improved considerably by the time minke whales had reached the Ross Sea. On the other hand, in years of low food availability along the ice-edge, body fat condition would still have been poor even when the minke whales reached the Ross Sea. The significance of food availability in the west ice-edge area for body fat condition may also have been enhanced by the normally much higher level of food availability in this area than in the Ross Sea area (Fig. 9).

In conclusion, minke whales appear to have been affected by a considerable interannual variability in food availability in the ice-edge area, which is potentially the most krill-rich area along their migratory route.

\section{Characteristics of Euphausia superba distribution}

Euphausia superba was the dominant prey species throughout the entire survey area, except on the 
Ross Sea shelf. According to earlier net sampling data (Kawamura 1974), however, Thysanoessa macrura dominates the offshore part of the survey area. The observed difference between whale stomach contents and net samples in the offshore area suggested that minke whales fed selectively on $E$. superba (Ichii \& Kato 1991). T. macrura has been reported to be an important food of baleen whales in the area from $100^{\circ}$ to $135^{\circ} \mathrm{W}$ (Nemoto \& Nasu 1958), where $E$. superba is considered scarce (Marr 1962, Mackintosh 1973). This area corresponds to one of the low density areas of minke whales (Kasamatsu et al. 1996).

Marr (1962) indicated that Euphausia superba was almost completely absent on the Ross Sea shelf, having been replaced by another euphausiid, E. crystallorophias. He speculated that the absence of the former may be partly ascribed to the failure of the warm deep current, which carries ascending larvae, to penetrate onto the shelf. This study, however, showed that E. superba were not completely absent from the shelf, but were codominant with E. crystallorophias as prey in the vicinity of the Bay of Whales, where minke whales were abundant. This may be partly due to the Bay of Whales being located close to the Ross Sea slope, where krill were dominant (Fig. 7).

In the case of fur seals and penguins, the size and maturity of Euphausia superba in their diet usually do not represent the krill stocks in the foraging areas. These predators tend to avoid juveniles (I) due to their small size and mature males (III B) due to their superior escape response (Hill et al. 1996, Ichii et al. 1996). Such absences of juveniles and mature males in the diet were not observed in the case of minke whales because they feed on krill by bulk swallowing; this implies that their diet may be used as an index of local E. superba stock

The spatial distribution of body size and maturity of Euphausia superba demonstrated an absence of juvenile krill in the Ross Sea area, indicating the unlikely use of this area as a krill nursery ground. Furthermore, adult krill in the Ross Sea area showed a lower maturation rate compared with other areas. In fact, no gravid (IIID) or spent (IIIE) female krill were observed in the Ross Sea area over the entire study period, indicating its apparent unsuitability as a spawning ground as well.

In the Antarctic Peninsula region, krill showed a distinct offshore-inshore difference in maturity stages, being at the reproductive stage in the offshore area, but non-reproductive in the inshore area. (e.g. Siegel 1988, Ichii et al. 1998). In the present study area, however, no such pattern was observed, suggesting that spawning and nursery grounds for krill may occur anywhere, except in the Ross Sea area.

\section{Paradox in the Ross Sea area}

The Ross Sea area, belonging to the high-Antarctic Zone where Euphausia crystallorophias and Pleuragramma antarcticum partly replace E. superba, was characterized by a low food supply (low stomach-content mass) throughout the study period, which agrees with some earlier studies (Hempel 1985, Hopkins 1987). Hempel (1985) considered that a marine ecosystem of this kind, having brief and irregular outbursts of primary productivity because of the short summer period, cannot sustain a high biomass of zooplankton, but only a rich community of benthic feeders. Furthermore, Tamura et al. (1997) estimated the consumption of krill by minke whales in the Ross Sea area as around 3 million tonnes, which is equivalent to the total standing stock biomass estimated for this area in late spring 1994 (Azzali \& Kalinowski 1997). The absence of baleen whales other than minke whales and blue whales from this area (Nishiwaki et al. 1997b) may also be attributed to the low food supply. Therefore, it is a paradox that minke whales, especially pregnant females with high energy requirements, are always numerous in the Ross Sea area. One of the reasons for this may be that animals which migrate along the iceedge are likely to accumulate in embayments, such as the Ross Sea. Also, pregnant females can reduce the effects of unfavorable weather by staying within the embayment, especially near the southern end. Since killer whales, a potential predator on minke whales, are also abundant in the area (Kasamatsu et al. 1990), the predator avoidance hypothesis cannot be evoked. In the Ross Sea area, a warming trend has been observed since the 1960s (Taylor \& Wilson 1990, Taylor et al. 1990), but it is unknown if this has changed the area into a sub-optimal place for feeding.

Acknowledgements. Our sincere thanks are due to all of the researchers and crew who were engaged in the collection and measurement of minke whale samples in the JARPA surveys.

\section{LITERATURE CITED}

Anon (1997) Report of the IWC workshop on climate change and cetaceans. Rep Int Whal Comm 47:293-319

Armstrong AJ, Siegfried WR (1991) Consumption of Antarctic krill by minke whales. Antarct Sci 3 (1):13-18

Arnold P, Marsh H. Heinsohn G (1987) The occurrence of two forms of minke whales in east Australian waters with a description of external characters and skeleton of the diminutive or dwarf form. Sci Rep Whales Res Inst 38:1-46

Azzali M, Kalinowski J (1997) Spatial and temporal distribution of krill Euphausia superba biomass in the Ross Sea (1989/90, 1994/95). Document WG-EMM-97/53, CCAMLR, Hobart

Bengtson JL (1988) Long-term trends in the foraging patterns of female Antarctic fur seals at South Georgia. In: Sahrhage $D$ (ed) Antarctic ocean and resources variability. 
Springer-Verlag, Berlin, p 286-291

Best PB (1985) External characters of southern minke whales and the existence of diminutive form. Sci Rep Whales Res Inst 36:1-33

Bushuev SG (1986) Feeding of minke whales, Balaenoptera acutorostrata, in the Antarctic. Rep Int Whal Commn 36 241-245

Croxall. JP, McCann TS, Prince PA, Rothery P (1988) Reproductive performance of seabirds and seals at South Georgia and Signy Island, South Orkney Islands, 1976-1987. implications for Southern Ocean monitoring studies. In Sahrhage D (ed) Antarctic ocean and resources variability. Springer-Verlag, Berlin, p 261-285

Everson I, Goss C (1.991) Krill fishing activity in the southwest Atlantic. Antarct Sci 3:351-358

Fujise Y, Nishiwaki S, Pastene LA (1997) An examination of the random sampling scheme of the JARPA surveys. Document SC/M97/14, IWC, Cambridge

Hempel G (1985) Antarctic marine tood webs. In: Siegfried WR, Condy PR, Laws RM (eds) Antarctic nutrient cycles and food webs. Springer-Verlag, Berlin, p 266-270

Hill HJ, Trathan PN, Croxall JP, Watkins JL (1996) A comparison of Antarctic krill Euphausia superba caught by nets and taken by macaroni penguins Eudyptes chrysolophus evidence for selection? Mar Ecol Prog Ser 140:1-11

Hopkins TL (1987) Midwater food web in McMurdo Sound Ross Sea, Antarctica. Mar Biol 96:93-106

Ichii T (1990) Distribution of Antarctic krill concentrations exploited by Japanese krill trawlers and minke whales. Proc NIPR Symp Polar Biol 3:36-56

Ichii T, Kato H (1991) Food and daily food consumption of southern minke whales in the Antarctic. Polar Biol 11 $479-487$

Ichii $T$, Hayashi $T$, Bengtson JL, Boveng $P$, Jansen JK, Cameron MF, Miura A (1996) Comparisons in diet between diurnal and overnight foraging chinstrap penguins at Seal Island. Document WG-EMM-96/55, CCAMLR, Hobart

Ichii T, Katayama K, Obitsu N, Ishii H, Nagganobu M (1998) Occurrence of Antarctic krill (Euphausia superba) concentrations in the vicinity of the South Shetland Islands: relationship to environmental parameters. Deep-Sea Res 45 $1235-1262$

Kasamatsu F, Joyce GG, Ensor P. Mermoz J (1990) Current occurrence of cetacean in the Southern Hemisphere results from the IWC/IDCR Southern Hemisphere minke whale assessment cruises, 1978/79-1987/88. Document SC/42/015, IWC, Cambridge

Kasamatsu F, Joyce GG, Ensor. P, Mermoz J (1996) Current occurrence of baleen whales in Antarctic waters. Rep Int Whal Commn 46:293-304

Kato H, Kishino H, Fujise Y (1990) Some analyses on age com-

Editorial responsibility: Otto Kinne (Editor),

Oldendorf/Luhe, Germany position and segregation of southern minke whales using samples obtained from the Japanese feasibility study in 1987/88. Rep Int Whal Commn 40:249-256

Kawamura A (1974) Food and feeding ecology in the southern sei whale. Sci Rep Whales Res Inst 26:25-144

Lockyer C (1987) The relationship between body fat, food resource and reproductive energy costs in north Atlantic fin whales (Balaenoptera physalus). Symp Zool Soc Lond $57: 343-61$

Mackintosh NA (1973) Distribution of post-larval krill in the Antarctic. Discovery Rep 36:95-156

Makarov RP, Denys CJ (1981) Stages of sexual maturity of Euphausia superba, Dana. BIOMASS Handb No 1.1:1-13

Marr JWS (1962) The natural history and geography of the Antarctic krill (Euphausia superba Dana). Discovery Rep $32: 33-464$

Nemoto T, Nasu K (1958) Thysanoessa macrura as food of baleen whales in the Antarctic. Sci Rep Whales Res Inst 13:193-199

Nishiwaki. S, Matsuoka $K$, Kawasaki $M$, Kishino $H$, Kasamatsu F (1997a) Review of the sighting surveys in the JARPA. Document SC/M97/1, IWC, Cambridge

Nishiwaki S, Matsuoka K. Hakamada T, Kasamatsu F (1997b) Temporal change in baleen whale abundance and biomass in the Antarctic. Document SC/M97/19, IWC, Cambridge

SC-CAMLR (1997) Report of the fourth meeting of the Scientific Committee, Annex 4. Rep. Ad Hoc Working Group on Ecosystem Monitoring. (SC-CAMLR-XVI/3). CCAMLR, Hobart

Siegel V (1988) A concept of seasonal variation of krill (Euphausia superba) distribution and abundance west of the Antarctic Peninsula. In: Sahrhage D (ed) Antarctic ocean and resources variability. Springer-Verlag, Berlin, p 219-230

Sokal RP, Rohlf FJ (1997) Biometry: the principles and practices of statistics in biological research, 3rd edn. WH Freeman and Company, San Francisco

Tamura T, Ichii T, Fujise Y (1997) Consumption of krill by minke whales in Areas IV and $V$ of the Antarctic. Document SC/M97/17, IWC, Cambridge

Taylor RH, Wilson PR (1990) Recent increase and southern expansion of adélie penguin populations in the Ross Sea, Antarctica, related to climatic warming. NZ J Ecol 14:25-29

Taylor RH, Wilson PR, Thomas BW (1990) Status and trends of adélie penguin populations in the Ross Sea region. Polar Rec 26(159):293-304

Watanuki Y, Kato A, Mori Y, Naito Y (1993) Diving performance of adélie penguins in relation to food availability in fast sea-ice areas: comparison between years. J Anim Ecol 62:634-646

Submitted: January 20, 1998; Accepted: September 8, 1998 Proofs received from author(s): December 11, 1998 